\title{
Crustal thinning in the Southwestern Iberia Margin
}

\author{
A. González ${ }^{\text {a) }}$, M. Torné ${ }^{(2)}$, D. Córdoba ${ }^{(1)}$, N. Vidal ${ }^{(2)}$, L.M. Matias ${ }^{(3)}$, J. Díaz ${ }^{(2)}$
}

\begin{abstract}
The mode of crustal thinning in the southwestem margin of the Iberian Peninsula is investigated along a transect that extends from onshore Iberia to the eastern end of the Horseshoe Abyssal Plain. On onshore areas, the crustal structure has been deduced using wide-angle seismic reflection data, whereas offshore we have used coincident steep and wide-angle reflection data along a NE-SW oriented seismic profile that extends from Cape San Vicente to the Horseshoe Abyssal Plain. In addition, 2D gravity modelling has been performed to validate the crustal structure deduced from seismic data. Our model results reveal that the crust undergoes a strong but continuous thinning from $31 \mathrm{~km}$ onshore Iberia to less than $15 \mathrm{~km}$ in the Horseshoe Abyssal Plain and that thinning occurs over horizontal distances of about $120 \mathrm{~km}$.
\end{abstract}

\section{Introduction}

The southwestern margin of the Iberian Peninsula has undergone complex tectonics since Mesozoic times. The study area (Figure 1) is located at the eastern end of the AzoresGibraltar fracture zone, which is considered as the boundary between two major plates, the Eurasian and African plates. In the West, from the Azores triple junction to $24^{\circ} \mathrm{W}$, the plate boundary is considered to be mainly divergent. Further east (from $24^{\circ} \mathrm{W}$ to about $18^{\circ} \mathrm{W}$ ) the boundary seems to follow the Gloria fault (Laughton et al., 1970), a $400 \mathrm{~km}$ long strike-slip fault with right lateral slip. At about $18^{0} \mathrm{~W}$ ocean-ocean convergence is occurring at a convergence rate less than $1 \mathrm{~cm} / \mathrm{yr}$ (Grimison and Chen, 1986) whereas the easternmost segment becomes a zone of continental collision as the boundary approaches the Iberian and African continental margins and continues into the Mediterranean region (e.g., Betics and Rif mountain chains).

The eastern segment of the Azores-Gibraltar zone comprises two regions with different evolution since Mesozoic times, namely the Gorringe Bank Region (GBR) and the Gulf of Cadiz (GC). During the last decades, several authors have hypothesized on the origin and evolution of the GBR. In 1975, Purdy proposed a mechanism for slow consumption of oceanic lithosphere that would account for the formation of the GBR. More recently, however, Sartori et al. (1994) concluded that there are no clear evidences to support any subducting model and that the slow rate of convergence and the oceanic nature of the lithospheres would prevent any subduction to occur. These authors support a diffuse plate boundary model where compressional stresses would be released from the whole lithosphere across wide areas.

(1) Dept. de Geofísica. Univ. Complutense de Madrid, Spain .

(2) Inst. of Earth Sciences, CSIC. Barcelona, Spain.

(3) Centro de Geofisica da Universidade de Lisboa, Portugal.

Copyright 1996 by the American Geophysical Union.

Paper number 96GL02299

0094-8534/96/96GL-02299\$05.00
The Gulf of Cadiz appears to be related to the unknown interference of the eastward displacement of the Gibraltar arc, the southern end of the Iberian paleomargin and the collision of the African and Eurasian plates (Banda et al., 1995).

The studied transect lies in an area that may represent the transition from the oceanic crust of the GBR (Purdy, 1975) to the continental crust of the Gulf of Cadiz and the Southwestern Iberian Peninsula (Gonzalez, 1996). Several seismic experiments were carried out during the 70 's and 80 's to study the crustal thickness in the onshore areas of southern Iberia (e.g., Mueller et al., 1973). These studies show that the crust is about $30 \mathrm{~km}$ thick close to the shoreline, with average crustal velocities of $6.0,6.4$ and $7 \mathrm{~km} / \mathrm{s}$, while upper mantle velocity falls within the range 7.9 $8.1 \mathrm{~km} / \mathrm{s}$. More recently, González et al. (1996), based on seismic refraction data have found that at the continental shelf of the Spanish margin of the Gulf of Cadiz the crust is $30 \mathrm{~km}$ thick.

The main goal of this work is to integrate marine deep multichannel seismic reflection data (MCS), and refraction and wide-angle reflection data collected in 1993 within the IAM project (Banda et al., 1995), and gravity data to determine the mode of crustal transition from continent to ocean along a $350 \mathrm{~km}$ long transect, running from the southwestern corner of Iberia to the eastern end of the Horseshoe Abyssal plain (HAP) (Figure 1).

\section{Seismic data}

The seismic data used in this study consist of an MCS profile, hereafter referred as profile IAM-3, and wide-angle data of airgun

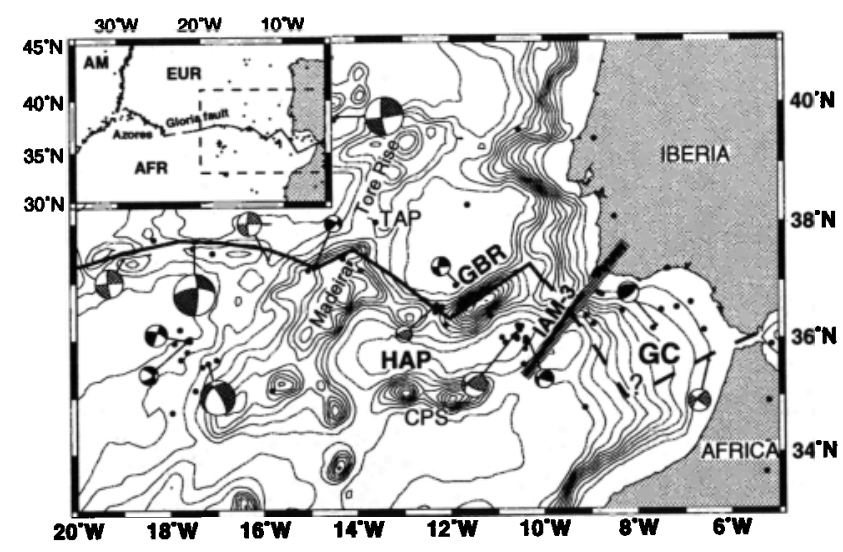

Figure 1. Location map of the study are a. Bathymetry at 100 $m$ interval. Thick line shows location of IAM-3 MCS profile. Gray strip shows location of the model transect. Solid triangles locate land recording stations. Focal mechanisms of earthquakes with magnitude $>5$ are shown, from: (Udías et al., 1976) black; (Grimison and Chen, 1986) dark gray; (various authors) light gray. Solid black dots show location of earthquakes with magnitude greater than 4. Thick gray line locates the plate boundary as proposed by Klitgord and Schouten (1986). Upper left inset shows global view of the area. AM: American plate. EUR: European plate. AFR: African plate. 
shooting recorded by 8 onshore stations deployed from the shoreline to $100 \mathrm{~km}$ inland.

The IAM-3 profile shows that the basement has a very reflective character (Figure 2a). The sedimentary cover is of variable thickness from $0.5 \mathrm{~s}$ (twtt) on the continental shelf and slope to about $2 \mathrm{~s}$ (twtt) in the central part of the profile. It comprises sediments from Aptian to Plio-Quaternary (Tortella et al., submitted), the most outstanding feature being the presence of a thick layer with a chaotic seismic image (CDP 2000-4000) of Upper Oligocene age. No deep crustal reflections are observed along the MCS profile (Figure 2a).

To improve the crustal seismic image of the crust, we analyzed the wide-angle data recorded by land stations (Figure $2 \mathrm{~b}$ ) in terms of conventional reflection seismics, using the same procedure as described by Gallart et al (1995). These data were also interpreted by ray-tracing forward modelling (Zelt and Smith, 1992). Figure $2 \mathrm{~b}$ shows as example the record section of station C3 located at 50 $\mathrm{km}$ from the shoreline. Clear $\mathrm{Pg}$ and $\mathrm{Pn}$ refracted phases, and PmP reflections are identified. The arrival time of $P$ phase is strongly influenced by the presence of a low velocity body, associated to the thick sedimentary cover observed in the central part of the MCS profile (Figure 2a). Some weak intracrust al reflected phases ( $P_{1} P_{\text {and }} \mathrm{P}_{2} \mathrm{P}$ in Figure 2b) are also observed from 65 to $85 \mathrm{~km}$.

The geometry of the reflection profile and the land recording stations provides multiple coverage along $70 \mathrm{~km}$, from about 25 $\mathrm{km}$ inland to the continental shelf break (Figure 3), covering the onshore/offshore transition. Therefore, we have processed that part of the profile using conventional reflection data processing. The analysis of wide-angle data has been focused on PmP Moho reflected phases, which are recorded for offsets ranging from 40 to $130 \mathrm{~km}$. Edition, muting and band-pass filtering (3-12 Hz) was applied to the wide-angle receiver gathers. A variable fold of 10 40 was achieved considering a bin-width of $500 \mathrm{~m}$, which resulted in a CMP gather built up from 3-4 land stations. A receiver gather mute of refracted waves was applied before processing, taking advantage that refracted phases were clearly separated and identified from the PmP phase. Further pre-stack conventional processing, namely predictive deconvolution, CMP sorting and NMO were applied to obtain the wide-angle stack section.

Figure 3 shows a combined section by merging the MCS and the wide-angle data in which a semblance coherency filter has been applied (Milkereit and Spencer, 1989). These results show that in the continental shelf, close to the shoreline, the base of the crust is located between 9 and $10 \mathrm{~s}$ (twtt), which is about $28 \mathrm{~km}$ considering an average crustal velocity of $6 \mathrm{~km} / \mathrm{s}$. As can be seen in Figure $2 b$ wide-angle data shows that the lower crust is characterized by a band of reflections marked as $P_{1} P$ and $P_{2} P$. Although no evidence of lower crustal reflections is observed in the MCS data, based on wide-angle information we have assumed that the Moho is located at the base of the lower crustal reflectivity zone. Onsh ore the Moho deepens to about $11 \mathrm{~s} \mathrm{(twtt)}$ in the Northeastern end of the profile (Figure 3).

\section{Modelling results}

Forward analysis of arrival times and amplitudes of wide-angle data (Figure 4a) shows a strong but continuous crustal thinning from $30 \mathrm{~km}$ onshore Iberia to less than $15 \mathrm{~km}$ at the southwestern end of the profile. The obtained velocity crustal structure, based on an unreversed data set, corresponds to a continental type crust. Onshore, the crust is characterized by the presence of three layers with velocities of $5.8-6.0 \mathrm{~km} / \mathrm{s}$ for the upper crust, $6.4 \mathrm{~km} / \mathrm{s}$ for the middle crust and $6.8-6.9 \mathrm{~km} / \mathrm{s}$ for the lower crust. Velocities in the uppermost mantle are $7.8-7.9 \mathrm{~km} / \mathrm{s}$. Offshore, the geometry of the sedimentary layers and water depth were taken directly from the interpretation of the MCS data, whereas the velocities of the sediments were derived from previous wide-angle/refraction studies (Purdy, 1975) and from the MCS data. A significant upper crustal thinning is inferred along the continental shelf, attaining minimum values at the southwestern half of the profile. The lower

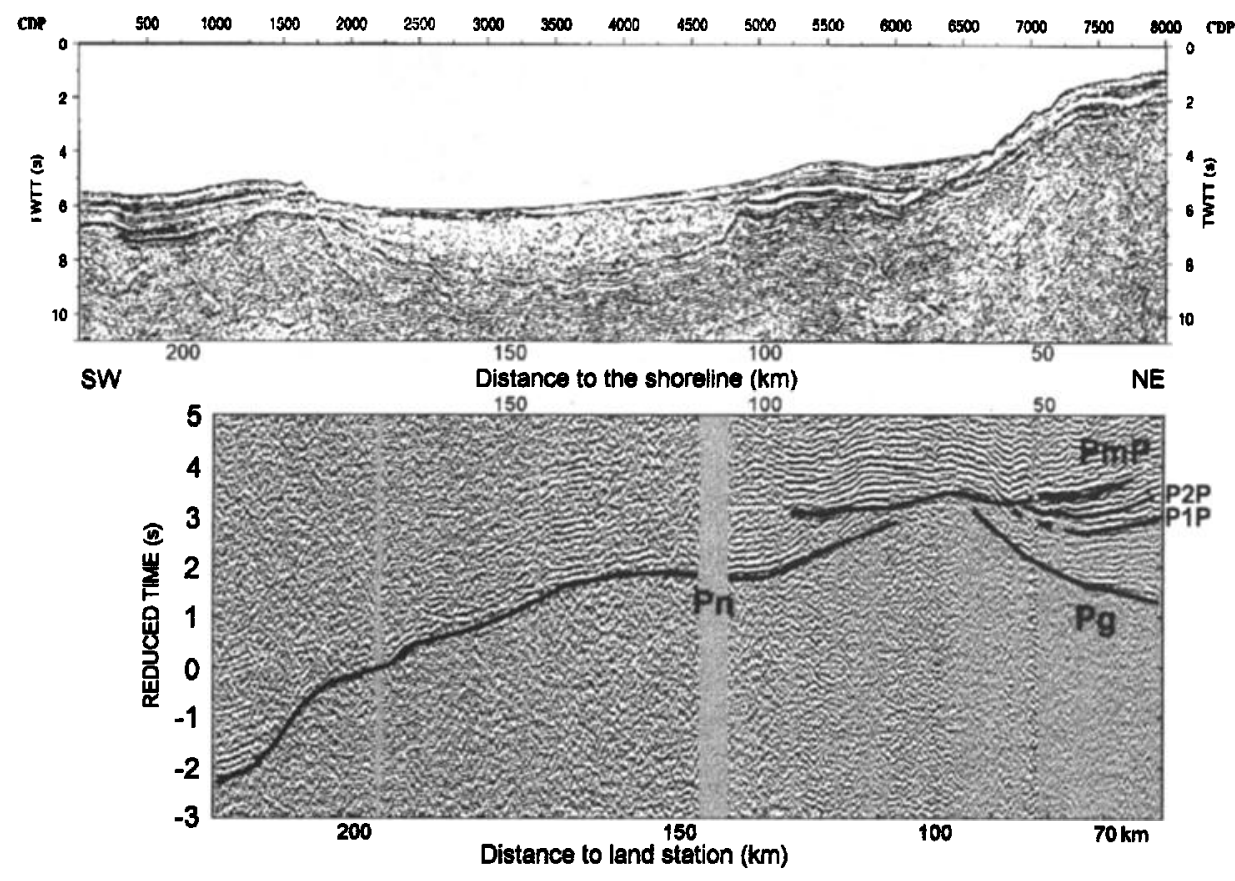

Figure 2. (a) IAM-3 MCS migrated profile. A lateral coherency filter has been applied to enhance seismic image (Milkereit and Spencer, 1989). TWTT: Two way travel time. (b) Wide-angle record section of land station C3, with a reduction velocity of $6 \mathrm{~km} / \mathrm{s}$, showing interpreted P-wave phases. Same horizontal scale at both profiles. 


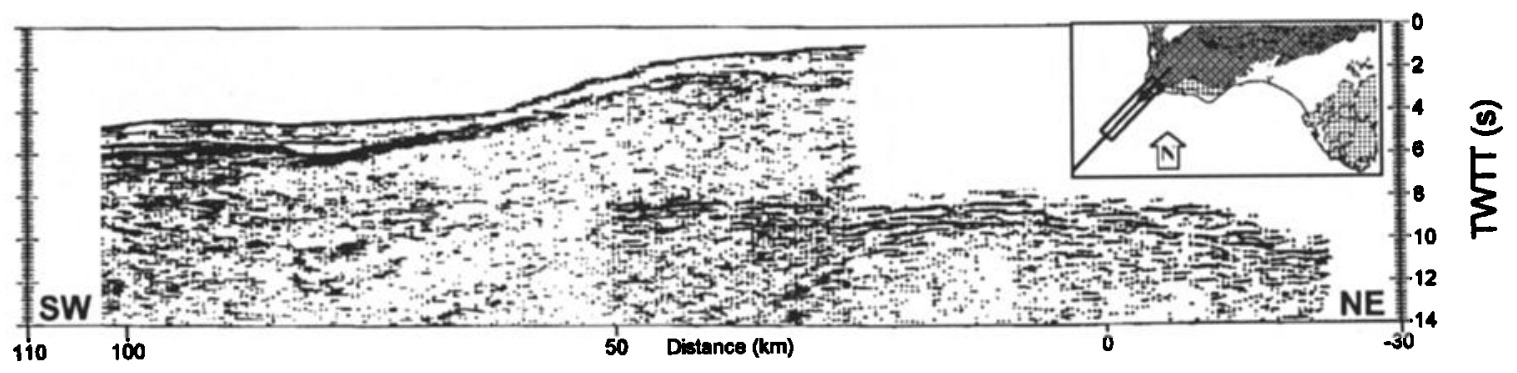

Figure 3. Time section after processing and merging the near-vertical and the wide-angle reflection data. Note that the Moho is seen at about 9-10 s (twtt) along the continental shelf. Inset shows location of coincident steep and large aperture seismic data.

crust $(6.8-6.9 \mathrm{~km} / \mathrm{s})$ thins out as the profile approaches the deep waters of the Horseshoe Abyssal plain, at $80 \mathrm{~km}$ from the shoreline. This fact suggests that an important part of the crustal thinning has been accommodated by the lower crust.

Owing to space limitations we show one example of the computed travel time curves of station $\mathrm{C} 3$, located at $50 \mathrm{~km}$ from the shoreline (Figure 4b).

2D gravity modelling (Figures $4 \mathrm{a}$ and $\mathrm{c}$ ) has been carried out to validate the obtained crustal velocity structure. Inland, we have used Bouguer anomalies (Torres and Lisboa, 1988), while at sea we have taken Free-Air gravity anomalies (Sandwell et al., 1994).

Free Air anomalies vary from $110 \mathrm{mGal}$ on the continental shelf to minimum values of $-70 \mathrm{mGal}$ on the deep waters of the Horseshoe Abyssal Pain. The gravity profile also displays two relative lows (from 50 to $90 \mathrm{~km}$ and from 100 to $180 \mathrm{~km}$ ) that are fairly coincident with the basement topography (See fig. 2a for comparison). Bouguer gravity anomalies vary from $30 \mathrm{mGal}$ in the northern part of the transect to $100 \mathrm{mGal}$ near the shoreline. The density model was obtained using the empirical velocitydensity relati onship of Ludwig et al. (1970). Figure 4c shows that the density model generates a gravity profile that is in fair agreement with the observed gravity data.

\section{Discussion and Conclusions}

The mode of crustal thinning in the southwestern Iberian Margin has been investigated using seismic refraction data and coincident steep and wide-angle reflection data along a $350 \mathrm{~km}$ NE-SW oriented transect, which extends from onshore Iberia to the HAP. In addition, 2D gravity modelling has been performed to validate the crustal structure obtained from seismic data.

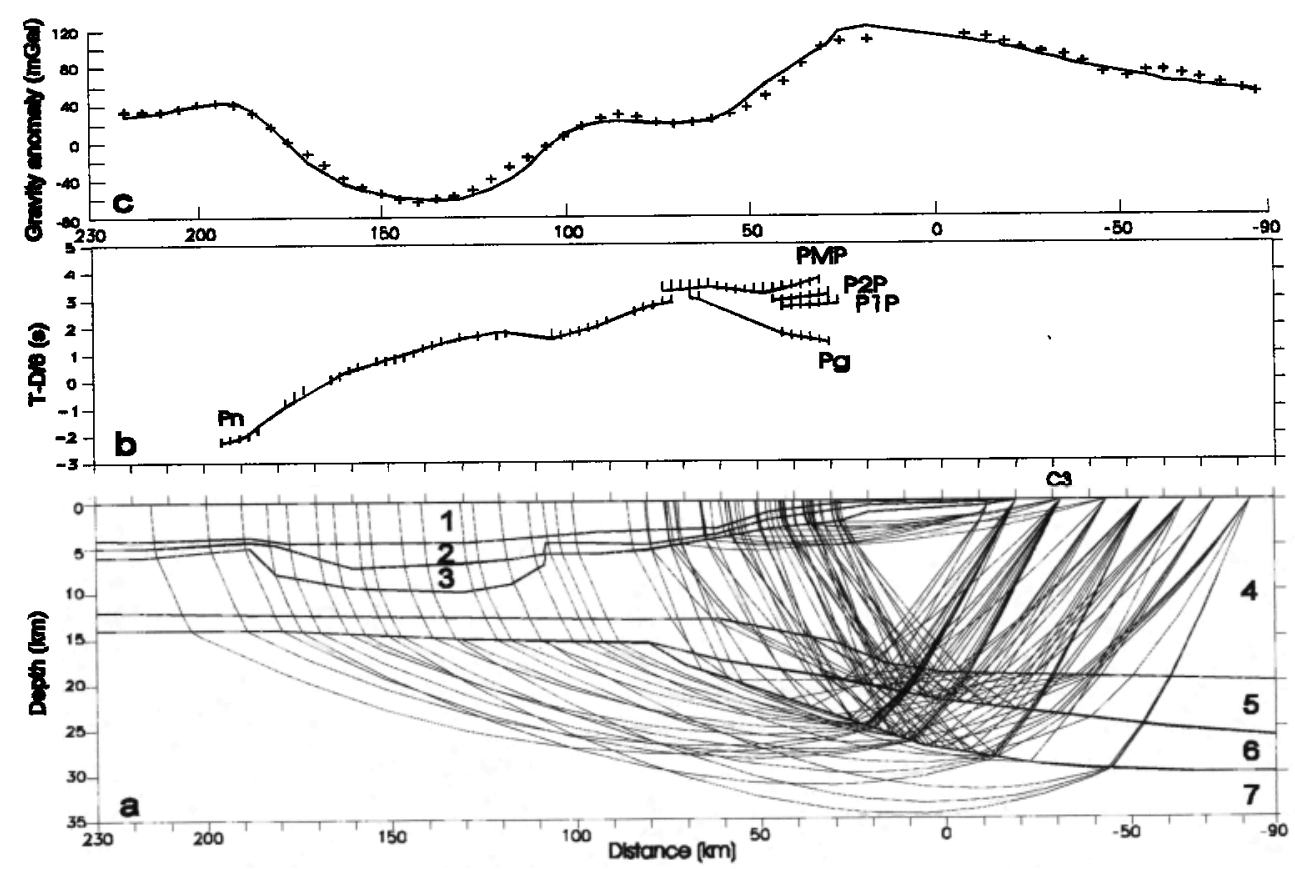

Figure 4. Best fitting forward modelling of wide-angle data and density model used to fit observed gravity anomalies. (a) Velocity model deduced from wide-angle data showing the ray tracing for the 8 land recording stations. (b) Comparison between observed (vertical lines) and calculated travel times (thick line) of the crustal model shown in panel (a) for station C3 shown in figure $2 \mathrm{~b}$. Vertical scale is reduced time by $6 \mathrm{~km} / \mathrm{s}$. c) Observed gravity values (crosses) and computed gravity anomalies (thick line) of 2D density model derived from the velocity model shown in panel (a). 1 (Water layer) $=1.5(\mathrm{~km} / \mathrm{s}), 1030(\mathrm{~kg} / \mathrm{m} 3) ; 2$ (Upper sediments)= 2.2, 2000; 3 (Lower sediments)= 3.7, 2400; 4 (Upper crust) = 5.8/6.0, 2700; 5 (Middle crust)= 5.8/6.0, 2750; 6 (Lower crust)= $6.8 / 6.9,2950 ; 7$ (Uppermost mantle) $=7.8 / 7.9,3300$. 
Our modelling results show that the crust thins from $30 \mathrm{~km}$ in the northeastern end of the profile to less than $15 \mathrm{~km}$ in the deep waters of the HAP. This crustal thinning occurs over horizontal distances of $120 \mathrm{~km}$, which resembles the crustal behaviour observed in other rifted passive margins such as Nova Scotia (Fenwick et al., 1968). This mode of crustal thinning is also quite similar to that obtained by Torne et al. (1995) along the Iberia Abyssal Plain and Tagus Abyssal Plain where the crustal thinning occurs across horizontal distances of about $110 \mathrm{~km}$.

Since from the deduced crustal velocity structure no clear evidences are found for an oceanic type crust, we suggest that the transect lies on a zone of transition from the continental domain of the Gulf of Cadiz (González, 1996) and the oceanic domain of the HAP and GBR region (Purdy, 1975). Away from the continental slope, the thickness of the crust ( $<14 \mathrm{~km}$ including water depth) and the slight anomalous upper mantle velocity (7.8-7.9 $\mathrm{km} / \mathrm{s}$ ) show some similarities with the crustal configuration found in the ocean-continent transition zone off the Tagus Abyssal Plain (Pinheiro et al., 1992). Therefore it appears more likely that the velocity structure of the model profile in its southwestern part is due to its proximity to the oceanic domain located further west. Some caution should be taken, however, since no deep reflected phases are available on this part of this profile to fully constrain the crustal velocity structure.

From our study we can not conclude that the plate boundary lies at the beginning of the MCS profile, as proposed by Klitgord and Schouten (1986) (Figure 1). Instead, our results together with results from other workers (e.g., Sartori et al., 1994) support a diffuse plate boundary model where convergence of Africa and Europe would be accommodated across wide areas.

Acknowledgments. Data acquisition and processing of the MCS IAM data were funded by EU project JOU2-CT92-0177. Additional funding was provided from CICYT project AMB93-1362-CE. This research has been supported by DGICYT project PB94-0013.

\section{References}

Banda, E., Torné, M. and Iberian Atlantic Margins Group. Iberian Atlantic Margins Group investigates deep structure of ocean margins. Eos Trans. $A G U, 76,3: 25-29,1995$.

Fenwick, D.K.B., Keen, M.J., and Lambert, A., Geophysical studies of the continental margins northeast of Newfoundland, Can. J. Earth Sci., 5: 483-500, 1968.

Gallart, J., Vidal, N. and Dañobeitia, J.J., Multichannel seismic image of the crustal thinning at the NE Iberian margin combining normal and wide angle reflection data. Geophys. Res. Lett. , 22, 4: 489-492, 1995.

González, A., Análisis de señales sísmicas. Estudio de la Estructura de la litosfera en el margen suroccidental Ibérico. Doctoral Thesis, Dep. de Física de la Tierra, Univ. Complutense, Madrid, 287 pp, 1996.

Grimison, N.L. and Chen, W.P., The Azores-Gibraltar plate boundary: Focal mechanisms, depth of earthquakes and their tectonic implications, $J$. Geophys. Res., 91: 2029-2047, 1986.
Klitgord and Schouten, 1986. Plate kinematics of the central Atlantic, in The Geology of North America. The Western North Atlantic Region, edited by P.R. Vogt and Tucholke, Geol. Soc. Am. Bull., Boulder, Colorado, 351-378, 1986.

Ludwig, W.J., Nafe, J.E., and Drake, C.L., Seismic refraction, in The Sea, vol. 4, Part 1, New Concepts of Sea Floor Evolution, edited by A.E. Maxwell, Wilet-Intersciences, New York, 53-84, 1970.

Milkereit, B., and Spencer, C., Noise suppression and coherency enhancement of seismic data, in Statistical applications in the Earth Sciences, edited by F.P. Agterberg and G.HF. Bonham-Carter, Geological Survey of Canada, 89, 243-248, 1989.

Mueller, S., Prodehl, C., Mendes, A.S. and Sousa Moreira, V., Crustal structure in the southwestern part of the Iberian Peninsula, Tectonophysics, 20, 307-318, 1973.

Pinheiro, L.M., Whitmarsh, R.B., and Miles, P.R., The ocean-continent boundary off the western continental margin of Iberia-II. Crustal structure in the Tagus Abyssal Plain, Geophys. J. Int., 109, 106-124,1992.

Purdy, G.M., The eastern end of the Azores-Gibraltar plate boundary. Geophys. J. R. Astron. Soc., 43, 973-1000, 1975.

Sartori, R., Torelli, L., Zitellini, N. Peis, D. and Lodolo, E., Eastern segment of the Azores-Gibraltar line (central-eastern Atlantic): An oceanic plate boundary with diffuse compressional deformation. Geology, 22, 555558, 1994

Sandwell, D.T., Yale, M.M. and Smith, W.H.F., ERS-1 Geodetic mission reveals detailed tectonic structures. EOS Trans. AGU, Fall 1994 AGU Meeting supplement, 115, 1994.

Torné, M., Fernàndez, M., Carbonell, J., and Banda, E., Lithospheric transition from continental to oceanic in the West Iberia Atlantic Margin, In: Rifted-Ocean Continent Boundaries, E, edited by E. Banda, M. Torné and M. Talwani, NATO-ASI Series, Kluwer Acad. Pub., 247-263, 1995.

Torres, L. and Lisboa, M., Standardization of gravity and magnetic data of part of Iberia including offshore area, in Proc. of the $5^{\text {th }}$ Workshop on the European Geotraverse (EGT) Project-the Iberian Peninsula, edited by E. Banda and L.A. Mendes-Victor, ESF, 111-121, 1988.

Tortella, D., Tomé, M. and Perez-Estaun, A., Geodynamic evolution of the eastern segment of the Azores-Gibraltar Zone: Gorringe Bank and Gulf of Cadiz Region, Marine Geophysical Researches, submitted.

Udias, A., Lopez-Arroyo, L., and Mezcua, J., Seismotectonics of the Azores-Gibraltar region, Tectonophysics, 31, 259-289, 1976.

Zelt, C.A. and Smith, R.B., Seismic traveltime inversion for 2-D crustal velocity structure. Geophys. J. Int., 108: 16-34, 1992.

A. González, Departamento de Geofísica. Univ. Complutense, 28040 Madrid (Spain).

M. Torné, Institute of Earth Sciences "J. Almera", Consejo Superior de Investigaciones Cientificas (CSIC). Solé i Sabaris s/n, 08028-Barcelona (Spain). (email: mtorne@ija.csic.es)

N. Vidal, Institute of Earth Sciences "J. Almera", (CSIC). Sole i Sabaris s/n, 08028-Barcelona (Spain).

L. Matias, Departamento de Geofisica da Universidade de Lisboa, Rua Politecnica, Lisboa (Portugal).

J. Diaz, Institute of Earth Sciences "J. Almera", (CSIC). Sole i Sabaris s/n, 08028-Barcelona (Spain). (email: jdiaz@ija.csic.es).

(Received May 7, 1996; revised July 16, 1996; accepted July 19, 1996) 